Governmental Studies during the CARP pro ject and is currently engaged in studies of organizations that operate technologies of such criticality that nearly failure-free per- formance is demanded.

David Hadwiger is a doctoral candidate and was project coordinator and field supervisor. He has recently returned from the
Defense Base Closure and Realignment Commission in Washington, D.C., where he was studying the effects of military spending on congressional re-elections.

\title{
Teaching the Political Ideas of the Bible
}

\author{
H. Mark Roelofs, New York University
}

$\mathbf{W}_{\text {hat follows is a syllabus for a }}$ 14-week, one-semester, four-point, undergraduate course in the political ideas of the Bible, both Old Testament and New. Prerequisite is a onesemester introduction to political theory.

Teaching the Bible in the American academic environment has hazards. In that mostly secular world, the phrase "Bible study" is reflexively taken to mean "religious devotions" or even "proselytizing." To avoid these implications, the older style was to call Bible courses in a regular college curriculum something like "The Bible As Literature." Tactics of that sort miss the pointvirtually all great literature, from the idolatry of Macbeth to Huck Finn faith-wrestling on his raft, addresses or is based on profound religious concerns.

My approach is that the Bible's consistent and profound religious concerns are necessarily accompanied by major political implications and conceptions. The point is both general and specific: generally, any religion, save the most solipsistic, must translate into social and political behavior in order to have practical significance; specifically, what most distinguishes the Biblical God from the time of Abraham forward-unlike all other ancient gods -is the distinction of being a god of history and of political action.

On the other hand, I argue that faith and action are personal responsibilities and that nothing is to be gained-either in the classroom or elsewhere-by trying to manipulate anybody. I further argue that this class is an "academic" enterprise in which dispassionate analysis and calm reflection will be highly praised.
(I am then forced to concede that both these injunctions are quite possibly expressions of a Protestant bias -and perhaps, more exactly, a Presbyterian one.)

\section{Syllabus} The Biblical Contribution to the
Western Political Tradition

The principal intent of this class is to extract political concepts from Biblical materials, identify them with

The principal intent of

this class is to extract

political concepts from

Biblical materials, identify

them with major strands

of the Western political

tradition generally, and, most important, define the concepts with

\section{precision.}

major strands of the Western political tradition generally, and, most important, define the concepts with precision.

In overview, we will find in the Biblical materials three distinct though related clusters or families of political concepts: those associated with the nation and its charismatic leader; those associated with revolution and the prophet who calls for it; and those associated with what is called here the confessional life and the seeker who pursues it. All of these concepts are indigenous to the Bible and are also powerfully present in the Western political tradition.

Two practical difficulties will inhibit our effort to identify these concepts: one has to do with us; the other with the Biblical materials.

Our difficulty is that, although we live in a Biblically shaped culture, as a generation of academics our Biblical illiteracy is very nearly total. We have been taught to equate the Bible with religion and, then, with obscurantism, superstition, pathetic subjectivism, personalism, or whatever else need be of no concern to professional objectivity and rational/scientific enlightenment. If we are to treat the Biblical materials with the intellectual seriousness that our present enterprise requires, we must overcome both ignorance and bias, each in near-absolute degree.

The difficulty with the Biblical materials is twofold. First, the Biblical writers, in their "primitivism," were wholly unconcerned with conceptual problems. Their philosophical competence was minimal. They regularly used terms interchangeably and exchanged meanings among related terms with what can only be regarded-by academics concerned with intellectual rigor-as literary abandon.

Nevertheless - and this is the second difficulty the Bible presents to practical research-the Biblical writers wrote with enormous effect. No book in history has had greater impact; no book has been a more powerful source of controversy. And the controversy continues-desperate, fundamental, urgent, and political. Moral majoritarians and liberation 
theologians, fundamentalists of the right and the left respectively, both claim stridently that theirs is a message of Biblical recovery.

Thus, ignorant and untried, we are entering into a marsh of indefiniteness surrounded by inflammatory controversy. There is, however, a probability that every one of us, whether by indifference, accident, or active commitment, has already taken sides on many of the issues we will encounter in the Bible. It may well be that the most important result of the course will be an increased personal clarity about where we each stand.

Be that as it may, the intellectual focus of the course remains, narrowly, philosophical and, even more specifically, phenomenological: to identify and define with precision, through an examination of historical roots, sets of political ideas, that is, frameworks of consciousness. By these, in the West, political actors have through acculturation come to structure their worlds of political experience and understand their roles, purposes, and actions in them. The Bible, as one major source of those ideas, deserves attention.

The course edition and translation of the Bible is: The Holy Bible: The New Oxford Annotated Bible (Revised Standard Version Containing the Old and New Testaments), ed. H. G. May and B. M. Metzger, New York: Oxford University Press, 1973.

Students, of course, are free to read any translation of the Bible they prefer (except the Reader's Digest edition!). The RSV is preferred for the course because it is a conscious editing of the King James translation and thereby preserves that translation's political and cultural significance-its sonorous language, its often crucially Protestant presuppositions-and its pervasive masculinism. Also, the annotations of the OUP edition are exceptionally helpful and comprehensive.

Other material (see Selected References) are on reserve in the library and will be assigned/recommended in class as required.

The syllabus that follows lists the Biblical readings assigned and the topics to be covered in class. It is detailed. If we hold to its pace week by week, class discussions can be remarkably free in scope and content.

Always bring your Bible to class. If necessary, disguise it as a comic book, a copy of Playboy, or an edition of the Wall Street Journal.

Part I of the course covers much factual material. There will be a short-answer quiz on it on a date to be determined. Parts II, III, and IV cover the major political concepts in the Biblical materials in sequence. On the date of the final examination, each student is to turn in a five-page essay discussing one or more of these concepts and its impact on the development of Western political thought. The final examination will contain both short and essay type questions.

\section{The Course}

\section{Introduction}

A. Political ideas

B. The Bible "sanitized" (1 Sam 2:1-10; Lk 1: 46-55)

C. A Demonstration: The Sermon on the Mount (Mt 5:3-7:29)

Editorial Comment: The course is introduced by making three points in rapid succession:

a. The approach of the course is governed by Kant's insight that ideas make experience possible, that intentional ideas make action thinkable. Political ideas are defined as preformations of consciousness by which we conceive of ourselves as subjects and situate ourselves in our worlds of political experience for action and interaction.

b. The Bible is packed with political ideas in this sense-many of them now ignored, forgotten, more or less deliberately misconstrued, or even actively suppressed. For example, Mary's song, and Hannah's on which it was probably based, are pleas from opposite ends of the Bible by distressed women to reverse the social order of their world.

c. Most of us have grown up having the Bible quoted at us in fragments ("sound bites"?). The impression inevitably left with us is that it is a book of sayings, almost a compendium of aphor- isms. But if we take, for example, the Sermon on the Mount, read it as a whole, pay special attention to the logic linking its parts, and place it in its social and historical context, a very different message will emerge.

\section{Part I: The Book}

A. The Place: The Fertile Crescent; Hills and Plains; "The World" (Deut 26:5-11; Gen 1-3; Jn 1: 1-5)

B. The Time: (1) Primeval History; (2) Patriarchs; (3) Exodus and Conquest; (4) Davidic Kingdom; (5) Disruption; (6) Fall of Samaria; (7) Fall of Jerusalem; (8) Exile; (9) Return; (10) Dispersion; (11) Rebellion; (12) The New Kingdom

Secondary Sources: e.g., Anderson, Kee, Rowley, encyclopedias

C. The Record: Tradition, Composition, Redaction, Preservation Examples: The Second Isaiah, Job, The Yahwist Epic, The Synoptic Gospels

D. The Mind: Existentialism and Nominalism; Subjectivism and Historicism; Choice and Prophecy; "Faith" and "Shalom"'; Love (Gen 21:1-21; Gen 22:1-19; Job 3; Ps 23, 121; Rom 12)

Editorial Comment: The Bible is a book of experience, of history remembered, experienced, anticipated, as well as confronted, interpreted, and recorded. Its place is "the fertile crescent," stretching from what is now Iraq across to the Mediterranean coast and down to Egypt. Its time is a story line, a series of dates (which must be memorized). Its method is authorship, oral and written, collection and compilation, and redaction. It is a book which, for all the diversity of its contents (songs, sagas, stories, ancestries, legends, histories, AND legislation, commandments, poetry, proverbs, AND prophecy, teaching, parables, ecstatic dreams), is composed with extraordinary consistency from a single point of view, a singular mind set-radically nominalistic, determinedly experiential, concerned always to ask the same questions: What do I do now, here? Whom 
should I fear? Whom should I love? What god should I serve? What does God require of me? Above all, the Bible is a book about, and by, and for people, actual men and women by name, who loved and feared, hoped and anguished, lived and died, asking these questions. If the whole of the book were to be compressed between two quotations, perhaps the best would be, first, the prayer of thanksgiving at the heart of the Pentateuch (beginning, "A wandering Aramean was my father, ..." Deut 26:5-11), and second, Paul's recipe for Christian living given in his letter to the Romans, 12:1-21.

In detailing all of the above, the contrast between the Hebraic mind set and the contrasting, philosophical mind set of the Greeks, especially Plato, will be everywhere emphasized.

\section{Part II: Nationalism}

A. The Covenant: The Chosen Choose, The Saga and the Mission, The Congregation of Love (Gen 12:1-3, Ex 24:1-8, Josh 24, Neh 8-9)

B. Charismatic Leadership: Man and Superman, Challenge and Response (Ex 3:1-4:23, Ex 19: 13-27, Ex 32)

C. Sovereignty and the Law: Identity and Obedience (Ex 20, Deut 12-26)

D. Kings and Priests: Samuel and Saul, David and Nathan (Deut 17:14-18:22, 1 Sam 7:3-12:25, 2 Sam 9-20, 1 Kings 1-2)

Editorial Comment: The most prominent of the political ideas buried in and presupposed by the Biblical narratives is the concept of the nation. The central figure in this concept is the people assembled. They are congregated in their assembly by their leader, their charismatic hero, who by his words, binds them in covenant with him and their god in one life. Their unity is in their enthusiasm for their shared history, their remembered saga, their current moment of crisis and choice, and their sense of promise and mission. Law in this vision is commandments to be obeyed; leadership is the hero's capacity to point the way forward; and legitimacy is history truly chosen. All this is the ideal represented by Moses and Joshua. Actual kings and their priests fall far short. Even David had to be tripped up by Nathan.

Machiavelli is the clearest embodiment of this ideal in modern political thought, but its traces are clearly visible in Rousseau, Burke, Hegel, and American nationalists such as Abraham Lincoln.

\section{Part III: Revolution}

A. The Half-Forgotten Dream: Nomadic Spartanism, Amphictyony, Theocracy (Gen 24, Judg 1-5, Ruth, 1 Sam 1-4:1a)

B. The Prophetic Challenge: Elijah, Amos, Ezekial (1 Kings 16:29-22: 40, Amos, Ezek 1:26-3:11)

C. The Prophetic Promise: Isaiah, Jeremiah, 2nd Isaiah (Is 6, 9:27, 11:1-9; Jer 8:18-22, 32:1-25; Is $40: 1-41: 16$ )

Editorial Comment: The most distinctive of the Hebraic-Biblical contributions to Western political tradition is the figure of the prophet. But to be understood, the prophetic figure must be set between two other concepts: Biblical utopianism and the Biblical understanding of revolution.

Biblical utopianism has as much to do with memories as it does with hopes. The Biblical narrative begins with memory, the patriarchal legends of the founders, Abraham, Isaac and Jacob, and their simple, nomadic, almost communistic way of life unsoiled by luxuries, or the corruptions of alien religions and the pursuits of power. There was also the amphictyonic memory of the time after the conquest of Palestine when the tribes composed a nation with a common language, history, laws, and religion, but no central government. Against these memories the prophets contrasted the nation's more current state, debauched, oppressive, idolatrous. Armed only with their fiery words and dramatic gestures, the prophets confronted the people and their kings, challenged them to choose again, to be done with their corrupting gods of the land and turn anew to the saving God of their ancestors. With this challenge to change gods came a hope, a promise that a revolution of souls and of faith renewed would usher in a radically restructured social world, a utopian fellowship of sharing and giving in which all would be governed by tenderness and love.

Of the great Western philosophers, Marx most fully recovers the prophetic sense of revolution, and the parallels between him and Amos are especially close. But Hegel and Burke before him also shared this sense that changes in devotion could have volcanic impacts on social organization. Moreover, Isaiahic utopianism is a staple especially of Eurpoean communal anarchism.

\section{Part IV: The Confessional Life: The Integration of Private and Public}

A. The New Covenant: Prayer, Confession, The Negation of History (Jer 31:27-34, Jer 15: 10-21, Job)

B. The New Messiah: The Suffering Servant, The Redefinition of Power (Is 52:13-53:12, Mk)

C. The New Church: The Redefinition of Community, The Redefinition of Vocation (1 Cor; Jn, Acts 2)

Editorial Comment: As the nation of Israel suffered calamity after catastrophe, individual members were driven to search within themselves to ask in prayerful, existential terms whether their tribal god could long sustain them. This search for a personal, existential root for the social self and its public concerns began with Abraham's attempted sacrifice of Isaac. It was sustained by the personal questings of the prophets, especially in the "confessions" of Jeremiah and his announcement of the New Covenant. In the Old Testament, this tradition comes to its fullest flower in the book of Job. In the New Testament, it is the dominant theme throughout. Everywhere the emphasis is on prayer, confessional faith, forgiveness, and love. It is of the utmost importance to stress that in the pages of the Bible this personal search for an existential root for self-hood is never seen as a reclusive withdrawal into a simple, quietistic pietism. On the contrary, it is always seen as a preparation for a fully integrated social activism. The most poignant expression of this in the Bible's record are the scenes in Gethsemane depicting Jesus' final 
prayers and arrest. But this tradition is also evident throughout the ministry of Paul as recorded in his letters, and it is especially evident in the lives of the first disciples.

The confessional life is an obvious ingredient in almost all the great autobiographies of the Western tradition. As such, it especially constitutes the core value of the Liberal Democratic tradition. The direct and intimate integration of the confessional life into an organized social activism was the central feature of much leftwing Protestant sectarianism, and it remains so among the liberation theologians of our own day.

REVIEW FOR

FINAL EXAMINATION

\section{Selected References}

Anderson, Bernhard. 1986. Understanding the Old Testament, 4th edition. Engle- wood Cliffs: Prentice-Hall.

Boman, Thorlief. 1960. Hebrew Thought Compared to Greek. Philadelphia: Westminster Press.

Brown, Robert McAfee. 1984. Unexpected News: Reading the Bible with Third World Eyes. Philadelphia: Westminster Press.

Buttrick, George A., ed. 1952-1957. The Interpreter's Bible, Vols. 1-2. New York: Abingdon-Cokesbury Press.

Chase, Mary Ellen. 1956. Life and Language in the Old Testament. London: Collins.

Cullman, Isaac. 1956. The State in the New Testament. London: SCM Press.

Kee, Howard et al. 1983. Understanding the New Testament, 4th edition. Englewood Cliffs: Prentice-Hall.

Miranda, Jose. 1974. Marx and the Bible. Maryknoll: Orbis Books.

Pederson, J. 1926. Israel, Vols. I and II. London: Oxford University Press.

Roelofs, H. Mark. 1988. "Hebraic-Biblical Political Thinking,"' Polity, Vol. XX, No. 4, Summer, 572-97.

Roelofs, H. Mark. 1988. "Liberation Theology: The Recovery of Biblical Radicalism," The American Political Science Review, Vol. 82, No. 2, June, 549-66.

Rowley, H. H. 1956. Growth of the Old Testament. London: Hutchinson Univer- sity Library.

Snaith, Norman H. 1960. Amos, Hosea, and Micah. London: The Epwith Press.

Wallis, Jim. 1976. Agenda for a Biblical People. New York: Harper \& Row.

Walzer, Michael. 1985. Exodus and Revolution. New York: Basic Books.

Welsh, D. R., trans. 1965. Encyclopedia of the Bible. Englewood Cliffs: PrenticeHall.

Yoder, John Howard. 1972. The Politics of Jesus. Grand Rapids: Eerdsmans Publishing $\mathrm{Co}$.

\section{About the Author \\ H. Mark Roelofs is professor of politics at New York University where he primarily teaches political philosophy. His most recent book is The Poverty of American Politics: $A$ Theoretical Interpretation, soon to be pub- lished by Temple University Press.}

\title{
Outcomes Assessment: One Department's Experience with Portfolios and Outside Evaluators
}

\author{
Joan Hulse Thompson, Beaver College
}

\author{
" Evaluation of students' over-all \\ performance is probably the most \\ neglected element of the major pro- \\ gram," John C. Wahlke reported for \\ the APSA Task Force on the Polit- \\ ical Science Major (1991, p. 55). \\ "Evaluation of the effectiveness of \\ the political science program itself is \\ an equally important, even more \\ rarely addressed problem,"' he con- \\ tinued (1991, p. 56). A survey of \\ outcomes assessment in political sci- \\ ence, published in the June 1991 \\ issue of $P S$, reports that "fewer than \\ one out of six responding institutions \\ had ... a policy . . . mandating the \\ collection of certain types of out- \\ comes assessment data" (Julian, \\ Chamberlain and Seay, pp. 206-07). \\ External mandates for assessment, \\ however, already exist in certain \\ states and are expanding rapidly.
}

The Department of Education has adopted "a nationwide requirement that all regional accrediting agencies include assessment components as part of their accreditation provisions" (Julian et al., p. 206). Some faculty are unaware or have chosen to resist the momentum behind this national movement. As political scientists, we should seek ways to influence the development of assessment tools, to prevent the misuse of the data collected, and to use outcomes assessment to further our educational goals.

The political science department at Beaver College began the task of developing a means of documenting and assessing learning in the major during 1988. Although we have come a long way, the process is still evolving, and significant changes have been made after each graduating class. Most of the pieces are now in place, but some of them are new for the class of 1992.

Our experience is shaped by the fact that, except for one cross-listed course and an occasional adjunct faculty member, our department consists of two people. While small departments are not uncommon, we share one tenured position, teaching additional courses each semester as overload. Most courses are offered on a two-year cycle.

Beginning with the class of 1989 , we took an existing senior thesis requirement and extended it into a small portfolio composed of the following: student learning goals prepared in the context of departmental goals; a sample of previous work in a political science course; and the 